\title{
高速度錩の切㓱耐久力および抗折力におよぼす サブゼロ処理の影響*
}

\author{
小柴 定雄** 田中和夫**
}

Sadao Koshiba and Kazuo Tanaka : Effect of Subzero Treatment on Cutting Durability and Deflective Strength of High-Speed Steel. The effects of subzero treatment on the cutting durabilities and the deflective strength of four kinds of high-speed steels, namely, low-tungsten high-speed steel, low-tungsten-cobalt high-speed steel, molybden-tungsten high-speed steel and 18-4-1 steel were investigated. It was found that the cutting durability of subzero-treated specimen after oil-quenching was almost the same as compared with that of a specimen which was repeatedly tempered after oil quenching, and that the deflective strength of the former was equal to or was smaller than that of the latter. From the results of these investigation, it was concluded that the subzero-treatment on cutting-durability of high-speed steel due to lathe-cutting was not very effective.

(Received. November 20, 1956)

\section{I. 緒 言}

高速度鋼のサブゼロ処理に関しては広く研究(1)-(3)され ているが，切刢性能に拉上ぼす影響については比較的少な い. K. J. B. Wolfe(4)は 2 種類の高速度鋼についてサブゼロ 処理し切㓱試験を行つたが，それによるとサブゼロ処理し たものは繰返焼戻したものに比してや〉劣るようであり， また S. M. Depoy(5) は高速度鋼に+ブゼ口処理して切㓱量 の增大したことを述べている. 本報告はこれらの点を明ら

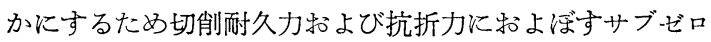
処理の影響を 4 種類の高速度鋼について実験した結果であ る.

II. 試料および実験方法

実験に使用した試料の化学組成を Table 1 亿示す.硬度

測定には $15 \mathrm{~mm} \phi \times 12 \mathrm{~mm}$, 抗折力測定には $5 \mathrm{~mm} \phi \times 70$ $\mathrm{mm}$ および切刢試験には $12 \mathrm{~mm} \phi \times 65 \mathrm{~mm}$ のバイトを用 いた、焼入温度は X $1 ， \mathrm{X} 00$ 拈よび $\mathrm{HX} 2$ は $1280^{\circ}(\mathrm{HX} 2$ のバイトは $\left.1300^{\circ}\right)$, XM 1 は $1260^{\circ}$ とし, 抗折力測定試

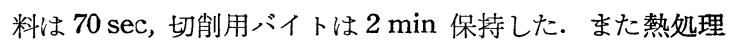
方法は (1) 油焼入 $\rightarrow$ 桲戻 (以下記号 T)，(2)油焼入 $\rightarrow$ 焼戻 $\rightarrow$ 焼戻 $(T \rightarrow T),(3)$ 油焼入 $\rightarrow$ 焼戻 $\rightarrow$ サブゼ口処理 $(T \rightarrow S)$, （4）油焼入 $\rightarrow$ サブゼロ処理 $\rightarrow$ 燒戻 $(\mathrm{S} \rightarrow \mathrm{T})$, (5) 油焼入 $\rightarrow$ 焼戻 $\rightarrow$ ザゼロ処理 $\rightarrow$ 焼戻 $(\mathrm{T} \rightarrow \mathrm{S} \rightarrow \mathrm{T}),(6)$ マルクェン チ $\rightarrow$ ザゼロ処理 $\rightarrow$ 焼戻 $(\mathrm{M} \rightarrow \mathrm{S} \rightarrow \mathrm{T})$, (7) マルクエンチ $\rightarrow$ 森戻 $\rightarrow$ サブゼ口処理 $(\mathrm{M} \rightarrow \mathrm{T} \rightarrow \mathrm{S})$ の 7 種とし, サブゼ 口処理は $-75^{\circ}$ に $20 \mathrm{~min}$,マルクエンチは $200^{\circ}$ に $30 \mathrm{~min}$ 拉よび矮戻は $575^{\circ}$ に $1 \mathrm{hr}$ 保持した. 抗折試験はアムスラ 一式引張試験機を用い, 支点 $50 \mathrm{~mm}$ の中央に压縮荷重を Table 1 Chemical composition of specimens.

\begin{tabular}{c|c|c|c|c|c|c|c|c|c|c}
\hline Mark & $\mathrm{C}$ & $\mathrm{Si}$ & $\mathrm{Mn}$ & $\mathrm{P}$ & $\mathrm{S}$ & $\mathrm{Cr}$ & $\mathrm{W}$ & $\mathrm{Mo}$ & $\mathrm{V}$ & Co \\
\hline $\mathrm{X} \mathrm{1}$ & 0.77 & 0.29 & 0.45 & 0.018 & 0.003 & 4.28 & 11.71 & - & 1.99 & - \\
$\mathrm{X} 00$ & 0.82 & 0.21 & 0.34 & 0.021 & 0.002 & 3.99 & 12.63 & - & 1.68 & 3.67 \\
$\mathrm{XM1}$ & 0.76 & 0.15 & 0.36 & 0.015 & 0.007 & 4.15 & 6.39 & 4.71 & 2.04 & - \\
$\mathrm{HX} 2$ & 0.80 & 0.22 & 0.37 & 0.028 & 0.002 & 3.95 & 18.06 & - & 0.82 & - \\
\hline
\end{tabular}
加完破断した時の荷重を測定し た.をた切刢試験は 6 呎米式精 密旋盤を用い, $\mathrm{Ni}-\mathrm{Cr}$ 鋼 110 $\sim 130 \mathrm{~mm} \phi\left(\mathrm{H}_{\mathrm{B}} 352\right)$ を切削し, 切削不能になるまでの時間を測 定した.な括この場合の切削条

** 日立金属工業株式会社安来工場

* 1956 年 10 月本会広島大会に発表

(1) 小柴, 田中, 稲田, 本誌, 18(1954), 521 .

(2) 近藤, 本誌, 19(1955), 62 .

(3) 岡本, 田中, 本誌, $20(1956), 285$.

(4) K. J. B. Wolfe, Mat. \& Meth. 25(1949), 129.

(5) S. M. Depoy, Trans. ASME, 66(1944), 645.
件は切込み $1 \mathrm{~mm}$ ，送り $0.5 \mathrm{~mm} / \mathrm{R}$ とした。

\section{III. 実 験 結 果}

\section{1. サブゼロ処理温度と硬度}

$15 \mathrm{~mm} \phi \times 12 \mathrm{~mm}$ の試料について, $1240^{\circ}$ 打よび $1280^{\circ}$

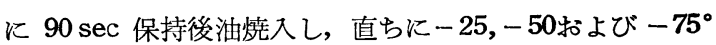
にサブゼロ処理して硬度を測定した. Fig.1 はその結果を 
示す. $1240^{\circ}, 1280^{\circ}$ 焼入のものともにサブゼロ 処理す ることによつて, またその温 度を低下するほど硬度を増

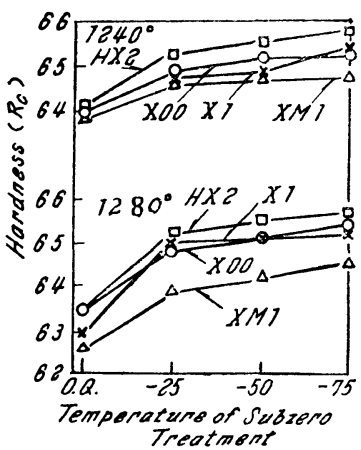
加するが, $1280^{\circ}$ 暁入のも のは $1240^{\circ}$ のものに比して 残留オーステナイトが多 く, 一 $25^{\circ}$ にサブゼロ処理 した場合の硬度の増加率は 大である・な括サブゼロ処 理後の硬度は -25〜-75 に沏いて両者にあまり差が ない. Fig. 2 は前述の $1280^{\circ}$ 油焼入後サブゼロ処

Fig. 1 Relation between 理したもの㧊よび油焼入の temperature of subzero ま〉のものについて階段的 treatment and hardness. に焼戻し硬度を測定した結

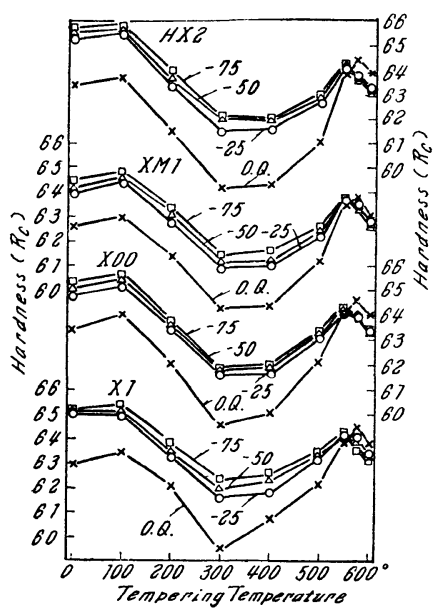

Fig. 2 Relation between temperature of subzero treatment and temper hardness.

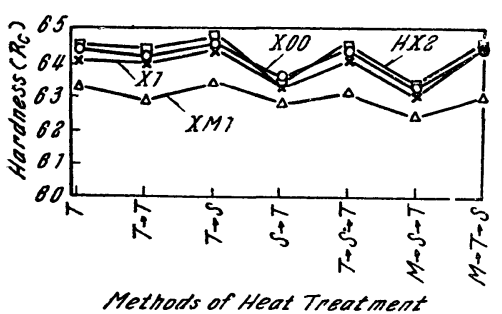

Fig. 3 Relation between methods of heat treatment and hardness.
果である. 各鋼 種とも曲線の傾 向は同様であ り，一般にサブ ゼ口処理温度が 低いほど硬度は 高く, また二次 硬化の起る温度 は油焼入のま〉 のものに比 し て, サブゼロ処 理したものは低 温側にずれるが -25〜-75 て はその温度执よ び硬度がほとん ぞ変りない。 ま た Fig.3 はさ きに示した 7 種 の熱好理を行つ た場合の硬度を 示す.な打熱処 理方法は記号で 示した.これに よると焼戻 1 回 行つたもの（T）に比し，油焼入直後にサブゼロ処理して 後焼戻したもの $(\mathrm{S} \rightarrow \mathrm{T})$ 特よびマルクエンチ後サブゼロ処 理して焼戻したもの $(\mathrm{M} \rightarrow \mathrm{S} \rightarrow \mathrm{T})$ は硬度がや〉低くなつて いるが，その他のものはほとんど変りない.この傾向は各 鋼種とも同様であるが XM 1 は全般的に低い. またこれら について顕微鏡組織を調べたが各処理を比較してあまり羑 がない.

\section{2.サフゼロ処理と抗折力}

Fig. 4は各種の熱処理を行つて抗折力を測定した結果で

ある. まず X 1 では $\mathrm{T} \rightarrow \mathrm{T}$ 処理したものが抗折力最も高 $く, \mathrm{M} \rightarrow \mathrm{S} \rightarrow \mathrm{T}$ 括よび $\mathrm{T} \rightarrow \mathrm{S} \rightarrow \mathrm{T}$ 処理のものがこれについ で高い. $\mathrm{S} \rightarrow \mathrm{T}$ 処理のものはこれらに比してかなり低い. $\mathrm{X} 00$ \& $\mathrm{T} \rightarrow \mathrm{T}$ 処理のものが他に比して高い. また XM1 は $\mathrm{T} \rightarrow \mathrm{S} \rightarrow \mathrm{T}$ 処理のものが最も高く, $\mathrm{M} \rightarrow \mathrm{S} \rightarrow \mathrm{T}$ 和よび $T \rightarrow T$ 処理がこれについで高い值を示している. HX 2 は

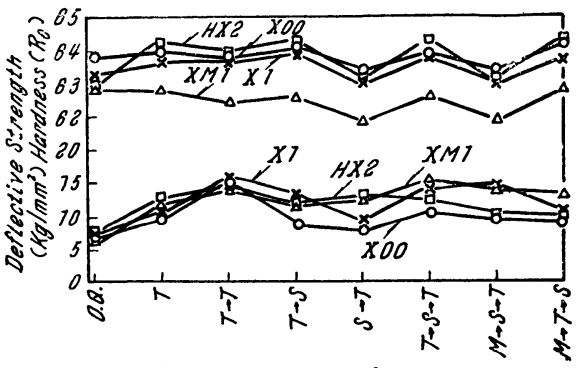

Methods of Heat Treatment

Fig. 4 Relation between methods of heat treatment and deflective strength.

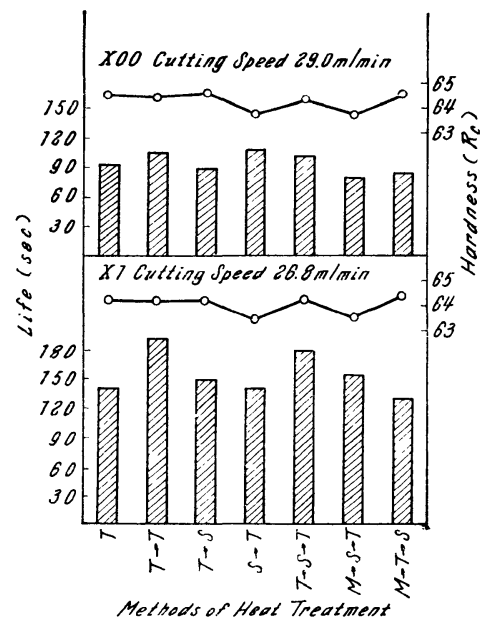

Fig. 5 Comparison of cutting durability due to variousheat treatment of X 1 and $\mathrm{X} 00$.

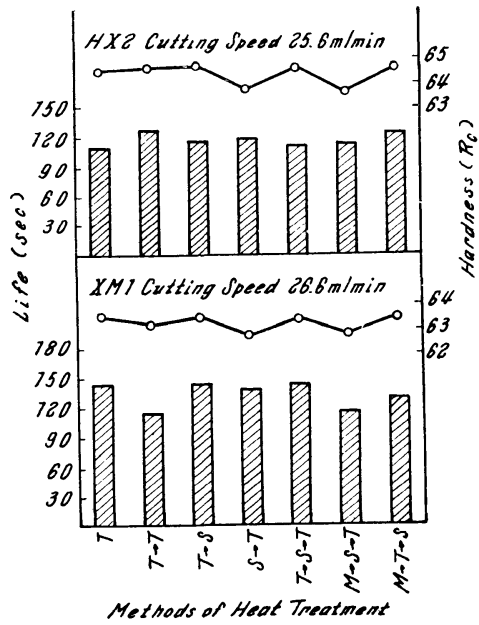

Fig.6 Comparison of cutting durability due to various heat treatment of XM 1 and HX 2.

\begin{abstract}
$\mathrm{T} \rightarrow \mathrm{T}$ 処理のも のがやはり高 い.この結果に よれば各鋼種の 傾向は必ずしも 一定でないが， サブゼロ処理お よびこれとマル クカンチ処理を 組合せたもの> 抗折力は焼戻 2 回行つたものと 比較して同等な いしはそれ以下 である。
\end{abstract}

\section{3. サブゼロ}

処理亡切削 耐久力

前述と同様汇 各種の熱処理し たものについて 切削試験を行つ た. Fig. 5 抌よ び Fig.6 はそ の結果を示す.

$\mathrm{X} 1$ では $\mathrm{T} \rightarrow \mathrm{T}$ 処理のものが切 刢耐久力最も大 であり， $\mathrm{T} \rightarrow \mathrm{S} \rightarrow$ T処理のものが

これについで良 好であるが，そ 
の他のものは大体同程度である. X 00 では $\mathrm{S} \rightarrow \mathrm{T}$ 抢よび $\mathrm{T} \rightarrow \mathrm{T}$ 処理のものが比較的良好である. また XM 1 は $\mathrm{T} \rightarrow$ $\mathrm{T}$ および $\mathrm{M} \rightarrow \mathrm{S} \rightarrow \mathrm{T}$ 処理のものがや〉劣つているが,その 他のものはあまり大差がない. HX 2 もあまり変りないが, $\mathrm{T} \rightarrow \mathrm{T}$ 拉よび $\mathrm{M} \rightarrow \mathrm{T} \rightarrow \mathrm{S}$ 処理のものが幾分よい傾向を示し ている.

\section{IV. 結果に対する考察}

上述の結果についてみるに，各鋼種とも油焼入後焼戻す こと汇より抗折力を增し,かつ 1 回焼戻より 2 回焼戻したも のが高いのはマルテンサイトを安定化し，かつ靱性を増大 するためである. 一方サブゼロ処理特よびマルクエンチ処 理を組合せたものは，2 回焼戻したものと同等ないしはそ れ以下の抗折力を示し，その効果はあまり認められない。 これは燒入後サブゼロ処理を行うと残留オーステナイトの 大部分はマルテンサイト化し，その後の䇢戻によつてマル テンサイトの焼戻軟化抵抗を減少するためと考兄られる。 また切㓱耐久力に和いては各処理のものを比較するにあま り大差がないが，X1 ではむしろ前述の理由で $\mathrm{T} \rightarrow \mathrm{T}$ 処理 したもの১方がサブゼロ処理したものよりもすぐれた傾向
を示している. したがつてこれらの結果から,この種高速 度鋼バイトのサブゼロ処理はあまり有効でないことが認め られ，むしろ焼戻処理を 2 回繰返し行つた方がよいと思わ れる.

\section{V. 結言}

上述の結果を要約すれば次の如くである.

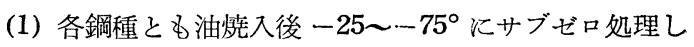
た場合は, サブゼロ処理温度が低いほど硬度は高くなる。 またこれを焼戻した場合は油焼入のま〉のものに比して, 二次硬化の起る温度が低温側にずれるが，-25〜-750で はその温度怙よび硬度がほとんぞ变りない，

（2）抗折力はサブゼロ処理款よびこれにマルクエンチを 組合せた処理を行つても, 本実験範围では油焼入後焼戻 2 回行つたものと同等ないしはそれ以下であり，この種サブ ゼロ処理はあまり効果的でないまたた切㓱耐久力について もサブゼロ処理したものは焼戻2回行つたものと大差なく， 期待した結果が得られなかつた．したがつてこの種旋削用 バイトは焼戻処理を十分行つた方が適当と思われる.

終りに本研究遂行に当り, 実験に協力された永島祐雄, 稲田朝雄両氏に深謝の意を表する. 